\title{
Вознесенский Свирский женский общежительный монастырь: повседневная жизнь общины в первой трети XVIII века
}

\begin{abstract}
Аннотачия. Статья посвящена изучению повседневной жизни и организачии управления в одном из первых женских общежительных монастырей Карелии в эпоху петровских преобразований. На примере конфликта, который возник в 1719-1720 г2. между насельничами Вознесенского монастыря, расположенного при впадении р. Свирь в Онежское озеро и входившего в состав Заонежской десятины Новгородской митрополии, разбираются вопросы, свлзанные с выбором кандидатуры на должность строительницы, со статусом вкладчиков и организачией хозяйства. Исследование основано на сопоставительном анализе документов судебного дела - челобитных, допросных речей, сказок, отписок, указов. Дополнительные сведения, выявленные в литературе, актах приказного делопроизводства и переписных книгах, позволили растирить представление об обстоятельствах и последствиях тяжбы. Установлено, ито во внутреннем укладе жизни общины переплелись традищии, восходившие к двум разным способам организачии монашеского быта. С одной стороны, насельницы имели общее имущество и стремилисъ следовать общежительному приниипу соборности в управлении обителью. Тем не менее некоторые случайные лича оказывались во главе общины и, стремясь выйти из-под ее контроля, превращались в деспотичных временшиков. $C$ другой стороны, в обители продолжали бытовать архаичные традииии особножития, которые были привнесены старичами, некогда проживавшими близ приходских черквей и составившими ядро общины. Отсутствие единения между сестрами, ослабление нравственной и духовной дисииллины были обычными явлениями не только для Вознесенского, но и для других монастырей Новгородской митрополии и Холмогорской епархии в последней трети XVII - первой трети XVIII вв. Церковные и светские власти предпринимали меры по искоренению и упорлдочению некоторых старинных практик, однако их действия не отличались последовательностью.
\end{abstract}

Ключевые слова: женское православное монашество, общежительный монастыръ, особножитие, институт поповских старост, локальное сообщество, традииии общинного самоуправления, Новгородская митрополия, Заонежскал десятина, Олонечкий уезд, Русская православная иерковъ.

Abstract. This article is dedicated to the study of the daily life and management organisation in one of the first female coenobitic monasteries in Karelia during the period of Peter the Great's reforms. On the example of the conflict that arose in 1719-1720 among the nuns of the Voznesensky monastery, located by the confluence of the Svir river into Lake Onega and part of the Zaonezhskaya tithe of the Novgorod metropolis, the author examines the questions related to the nominations for the post of monastery builder and contributors, and the general organisation of the household. This research is based on a comparative analysis of the documents from the legal case: petitions, interrogation speeches, accounts, formal replies, ordinances. The additional information derived from literature, acts of writ proceedings, and census books has allowed to broaden our perception of the circumstances and consequences of the litigation. It was discovered that within the community's inner order of life different traditions became intertwined, ascendants of two diverse ways of organising monastic life. On the one hand, nuns possessed common property and sought to follow the coenobitic principle of collegiality in the monastery's management. Nonetheless, some chance individuals came to head the community and, seeking to get out of its control, became despotic temporary workers. On the other hand, the monastery was also inhabited by archaic traditions of idiorrythmic monasticism that were introduced by the elders who had previously lived near parish churches

Исследование выполнено при финансовой поддержке Минобрнауки России в рамках проектной части государственного задания в сфере научной деятельности № 33.1162.2014/К. 
and constituted the core of the community. The lack of unity among the sisters and the weakening of the moral and spiritual discipline were commonplace occurrences not only for the Voznesensky monastery, but also for other monasteries of the Novgorod metropolis and Kholmogory diocese in the last third of the 17th-first third of the 18th centuries. Ecclesiastical and secular authorities undertook measures to eradicate and order some of the ancient practices, but their efforts, however, were not marked by consistency.

Key words: female Orthodox monasticism, coenobitic monastery, idiorrythmic monasticism, institute of priest elders, local communities, traditions of community self-government, Novgorod metropolis, Zaonezhskaya tithe, Olonetsky Uyezd, Russian Orthodox Church.

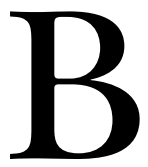

обзорном аналитическом очерке, посвященном осмыслению накопленного историографией опыта изучения женского монашества в России, Е. Б. Емченко подчеркнула, что «история женских православных монастырей <...> как в Средние века, так и в Новое время почти не разрабатывалась российскими учеными» $[1,245]$.

Этот вывод справедлив и в отношении первых женских обителей пограничного со Шведским королевством Олонецкого края. Вопросы, связанные с их учреждением, организацией в них духовной и хозяйственной жизни, подняты лишь в некоторых статьях и разделах монографий. В частности, И. А. Чернякова, опираясь на акты приказного делопроизводства и массовые источники, пересмотрела общепринятые в историографии положения из истории Андрусовской пустыни в последней четверти XVI - первой четверти XVIII вв. На основе сравнительного анализа инвентарных описей 1685 и 1715 гг,, представленных в них сведений об убранстве храмов и усадьбе автор выявила состав насельниц, особенности внутреннего уклада жизни обители до и после ее преобразования из мужской в женскую [2].

Ю. Н. Кожевникова оценила состояние монастырей Карелии, действовавших в первой половине XVIII в. Изучив делопроизводственные материалы, главным образом ведомости о монашествующих, автор привела данные о количестве инокинь трех первых женских обителей: Вознесенской в устье р. Свирь (16841764 гг.), Никольской на о. Брусно в Онежском озере (1684-1764 гг.) и Успенской в г. Каргополе (1677 г.) [3, 65-66, 74, 92, 94, 174]. Значительно большее внимание исследовательница уделила истории складывания двух сестринских общин, которые получили статус монастырей в начале XX в.: Паданского Введенского (1900 г.) и Ладвинского Кирико-Иулиттинского Боголюбского (1903 г.) [3, 108, 134-135, 137-143].

В фондах Национального музея Республики Карелия Ю. Н. Кожевникова обнаружила «Лето- пись о Вознесенской пустынской церкви», которую составили в 1870-1890-е гг. приходские священники - Симеон Лесков и Евгений Крылов [4, 71]. Сопоставив сведения летописи с изданным археографической комиссией в середине XIX в. царским указом от 12 апреля 1682 г., автор установила обстоятельства преобразования Вознесенской мужской пустыни в женскую.

В опубликованных в последнее десятилетие работах исследователи поставили вопросы об устройстве первых женских монастырей Карелии, обстоятельствах их учреждения в последней трети XVII в. и закрытия после подписания Екатериной II указа о секуляризации 1764 г. Приведенные авторами сведения позволяют утверждать, что сестринские общины, основанные почти одновременно на месте упраздненных мужских и функционировавшие менее столетия, представляли собой уникальный, но до сих пор не изученный феномен в истории женского православного монашества в северо-западном пограничном регионе Российского государства.

Наличие множества «белых пятен» в истории женских карельских обителей в раннее Новое время во многом связано не только с недостатком, но и с недоступностью источников, написанных скорописью XVII в., сильно обветшавших и выдаваемых только в читальных залах нескольких архивохранилищ страны. В то же время опыт исследовательской работы убеждает в том, что под обложками отдельных дел с общими заголовками скрываются целые комплексы документов, содержащие разнообразные по структуре и информационной насыщенности сведения, внимательный анализ которых позволяет реконструировать, казалось бы, безвозвратно канувшее в Лету прошлое.

\section{Внутренняя жизнь монашеской общины}

Вознесенский женский общежительный монастырь, располагавшийся на правом берегу р. Свирь при впадении ее в Онежское озеро, 


\section{Исторический журнал: научные исследования № 5 (29) • 2015}

DOI: $10.7256 / 2222-1972.2015 .5 .17277$

был учрежден царским указом от 12 апреля 1684 г. на месте упраздненной одноименной мужской обители. По велению новгородского владыки Корнилия братия во главе со строителем Филаретом переселилась в соседний Муромский монастырь [4, 72-73]. Спустя тридцать пять лет после этого - в 1719 г. - между сестрами возникли разногласия, разрешить которые самостоятельно им так и не удалось.

Судебное разбирательство, начатое в августе 1719 г., велось под руководством «духовных и гражданских дел судии» архимандрита Серапиона Аничкова в канцелярии митрополита новгородского, кафедру которого замещал с 1716 по 1721 гг. епископ Корельский и Ладожский Аарон (Еропкин). В начале 1720 г. дело было передано в Монастырский приказ. На данном этапе исследования у нас нет сведений о том, чем оно завершилось. Однако снятая с подлинника копия, содержащая материалы первичного розыска, сохранилась в фонде 480 («Новгородская духовная консистория») Государственного архива Новгородской области под заголовком: «Следственное дело по доносу на священника Остречинского погоста Дмитрия Евстафьева, обвиняемого в прелюбодеянии и взяточничестве». Священник Дмитрий Евтифеев (в описи ошибочно: «Евстафьев»), чье имя фигурирует в заголовке, как удалось установить, занимал должность поповского старосты «трех станов» Заонежской десятины, входившей в состав Новгородской митрополии. Он и вкладчица обители Пелагея Бестужева были обвинены одной из инокинь - Пелагеей по прозвищу Свеча - в нравственных проступках, своевольном управлении обителью и «истощении» монастырской казны.

В деле представлены копии девятнадцати документов на 44-х листах. Беглой скорописью конца XVII в. переписаны одним почерком - вероятно, подьячего, служившего в приказе новгородского митрополита, - челобитные и допросные речи насельниц, поповского старосты, монастырских «служебников» и крестьян, указы епископа Корельского и Ладожского Аарона (Еропкина) подьячим и стряпчим с подробными инструкциями по организации следствия, а также отписки последних.

Анализ свидетельских показаний насельниц, священнослужителей, «служебников» и работников об обстоятельствах возникновения житейской ситуации - в сопоставлении с нормами действовавшего законодательства - по- зволяет не только реконструировать внутренний уклад жизни в монастыре, но и оценить духовное и нравственное состояние общины в первой трети XVIII в. Отношение епархиальной и светской властей к тем явлениям, которые имели место в монастыре, может быть прослежено сквозь призму резолюций на челобитных и указах епископа, а также на основе сведений, почерпнутых из литературы. Сравнение традиций, сложившихся в монастыре, с практиками, распространенными в других обителях Новгородской и Холмогорской епархий, представляет уникальную возможность для более глубокого осмысления роли первых «девичьих» монастырей в развитии женского православного монашества и их места в жизни локального сообщества на пограничной окраине Российского государства.

\section{Участники конфликта и этапы разбирательства тяжбы}

В монастыре накануне конфликта проживали четырнадцать сестер во главе со строительницей Феклой. Девять из них - казначея Варвара, Екатерина, Пелагея Свеча, Антонида, Анна, Феодора, Маремьяна, Евфимия и Ираида - уже приняли постриг [5, л. 6-7, 23, 26об., 33об., 42]. Четыре - девки Татьяна и Ксения, вдовы Параскева и Татьяна - являлись «белицами», то есть ожидали пострижения, соблюдая монастырский устав [5, л. 20об., 34об.]. Выявленные сведения согласуются с данными реестра о монашествующих за 1722 г., которые привела Ю. Н. Кожевникова. Исследовательница установила, что в этом году в обители несли молитвенный подвиг тринадцать монахинь во главе со строительницей Агафьей (Карсаковой) $[3,65]$.

Отметим, что сестринская община Андрусовского девичьего монастыря, располагавшегося к северу от истока р. Свирь на восточном берегу Ладожского озера, в 1715 г. включала, как выяснила И. А. Чернякова, 44 женщины со строительницей Феклой $[2,24]$. В то же время в Брусненском девичьем монастыре, находившемся на одноименном острове в Онежском озере, в 1722 г., по данным Ю. Н. Кожевниковой, состояли строительница София и пять монахинь $[3,65]$. Приведенные сведения убеждают в том, что община Вознесенского монастыря в конце 1710-х гг. была не столь многочисленной, однако и не совсем крошечной. 
Социальная история

DOI: $10.7256 / 2222-1972.2015 .5 .17277$

Помимо насельниц при обители проживали «служебники» и вкладчики, мнение которых обязательно учитывалось при принятии решений, связанных с выбором тех или иных должностных лиц и расходованием казны [5, л. 26об.]. В материалах судебного дела выявлены имена пяти «служебников» - Мартина Никитина Ступина, Никифора Козьмина, Никиты Нефедьева, Афанасия Иванова Раптева и Семена Щепихина [5, л. 5, 22об., 38]. Других работников в монастыре, вероятно, и не было, так как согласно царскому указу от 30 декабря 1701 г. в обителях повелевалось «оставить самое малое число» работников, без которых «по самой нужде быть невозможно» $[6,182]$. В числе вкладчиков упоминаются двое: «служебник» Семен Щепихин и вдова Пелагея Бестужева. Таким образом, в Вознесенском девичьем монастыре к лету 1719 г. насчитывалось около двадцати человек, не включая наемных работников, исполнявших те или иные поручения.

Судебное разбирательство затянулось более чем на полгода. Монахиня Пелагея Свеча подала исковую челобитную в канцелярию новгородского митрополита 16 июля 1719 г. Выдвигая различные обвинения против поповского старосты Дмитрия Евтифеева и вкладчицы Пелагеи Бестужевой, челобитчица заявляла, что «для $<\ldots>$ их <..> неистовства чинитце тому монастырю великое разорение и зазор, и монахиням жить невозможно» [5, л. 2об.]. Очные ставки Пелагеи Свечи с вкладчицей Пелагеей Бестужевой и с поповским старостой Дмитрием Евтифеевым в присутствии архимандрита Серапиона Аничкова состоялись 19 августа и 18 сентября соответственно [5, л. 3-7, 26-28].

С сентября по ноябрь 1719 г. стряпчий Богдан Неелов по заранее подготовленному в канцелярии митрополита вопроснику допросил 16 человек - «того монастыря священнослужителей и монахинь, и служебников, и вкладчиков» [5, л. 13-21]. Так и не разыскав двух главных свидетелей - «служебника» Семена Щепихина и оштянина Евсея Кагача, - стряпчий отправил к 23 ноября в Великий Новгород подготовленные им протоколы допроса [5, л. 22, 42-43].

Между 23 ноября 1719 г. и 28 января 1720 г. в присутствии епископа Корельского и Ладожского Аарона (Еропкина) состоялось судебное заседание. Однако в Монастырском приказе сочли необходимым продолжить розыск, повелев священнику Дмитрию Евтифееву, на время отпущенному домой, вновь «явитца в митрополиче розряде» к 9 мая 1720 г. [5, л. 24].

\section{Спор о кандидатуре на должность строительницы: «раскол» общины}

Из допросных речей, составленных стряпчим Богданом Нееловым, можно заключить, что разногласия в общине возникли вскоре после того, как прежняя строительница Фекла, по показаниям насельниц часто пребывавшая «в скорби и в безпамятстве» и «во изступлении ума», весной 1719 г. была отстранена поповским старостой от должности [5, л. 3, 20, 26об.].

Разногласия начались с выбора новой строительницы. Некоторые насельницы, в том числе казначея Варвара, и духовник общины иеромонах Лаврентий утверждали, что на эту должность была выбрана монахиня Пелагея Свеча [5, л. 14об., 16об.]. Для обоснования законности процедуры выбора сама инокиня указывала, что ее избрали по общему согласию и «о том дали $<\ldots>$ поповскому старосте за руками челобитную» $[5$, л. 1].

Другие сестры - монахини Анна, Евфимия и Маремьяна, а также белицы Параскева и Татьяна - заявляли, что «на место прежде бывшей того монастыря строительницы Феклы помянутую истицу монахиню Пелагею не выбирали» $[5$, л. 20об.]. Они подчеркивали, что «по совету всех монахинь» в строительницы прочили другую монахиню - Антониду [5, л. 3, 20об.]. Вкладчица Пелагея Бестужева уточняла, что Пелагею Свечу выбрали лишь «некоторые монахини <...> тайно» $[5$, л. 3].

Эта версия частично подтверждалась показаниями поповского старосты Дмитрия Евтифеева, который признался, что о выборе в строительницы Пелагеи Свечи спрашивал только «у обретающихся тогда в монастыре монахинь и служебников» и не знал, «ведали ль» о том монахини и «служебники», «бывшие во время того выбору <...> в монастырских селах» [5, л. 26об.].

Из показаний насельниц ясно, что все они так или иначе апеллировали к традиции выбора должностных лиц всей общиной, с учетом мнения вкладчиков и «служебников». Е. В. Барсов и В. М. Верюжский установили, что эта традиция соборного принятия решений была широко распространена в монастырях Карелии и Поморья в последней трети XVII - первой половине XVIII вв. [7, 13; 8, 263]. М. М. Богословский предположил, что такой способ «организации монастырского управления» отражал «в себе устройство управления земских миров», представители которых поступали в число братии $[9$, 


\section{Исторический журнал: научные исследования № 5 (29) • 2015}

DOI: $10.7256 / 2222-1972.2015 .5 .17277$

83]. В то же время, по мнению В. В. Бовыкина, именно общежительные монастыри, управление которых было основано на строгом соблюдении принципа соборности, способствовали в ходе колонизации центральных, а позднее северных и северо-восточных земель Российского государства становлению традиций общинного самоуправления $[10,55,57]$.

Хорошо знакомая сестрам процедура самостоятельного выбора настоятельницы не являлась для них формальной. Ее нарушение поповским старостой Дмитрием Евтифеевым - намеренное или случайное - привело к назревавшему исподволь расколу общины на два лагеря. Во главе одного из них стояла монахиня Пелагея Свеча, а во главе другого - обвиняемая ею вкладчица Пелагея Бестужева.

Тщательный анализ взаимных обвинений, выдвинутых челобитчицей и ответчиками, как и показаний насельниц, позволяет составить представление о том, кто принял сторону Пелагеи Свечи. Несмотря на то что свидетельства сестер разнились, все они подтвердили, что именно Пелагею Свечу прежняя настоятельница Фекла временно «определила <...> служить за монастырскими ключами к роздачи хлеба и харчевых припасов» $[5$, л. 17об.].

Занимая должность казначеи, инокиня так и не заручилась поддержкой общины, но, напротив, проявив самовластие, вызвала всеобщее недовольство. Спустя всего «недели с три» монахиня Екатерина отправилась к поповскому старосте в Остречинский погост и от имени всех сестер пожаловалась на казначею. На допросе в присутствии стряпчего Богдана Неелова сестры не скрывали, что остались недовольны тем, как новая казначея исполняла послушание у «раздачи хлеба и харчевых припасов» [5, л. 17об.]. Насельницы, которые ранее не выражали открытого недовольства по поводу избрания в строительницы Пелагеи Свечи, теперь не преминули заявить о своем несогласии церковным властям. К ним, по всей видимости, присоединились и те, которые первоначально поддержали Пелагею Свечу. Казначея вынуждена была бежать в деревню Княжбор, отстоявшую в нескольких верстах от монастыря, где пребывала до высылки в Великий Новгород «с полмесяца» [5, л. 7]. По мнению поповского старосты Дмитрия Евтифеева, именно там она сговорилась с подьячим «архиерейского розряду» Григорием Тишиным, который бывал в монастыре с разными поручениями и помог ей составить челобитную [5, л. 25].
Хотя Пелагея Свеча считала, что «ложный» донос на нее был сделан монахиней Екатериной по настоянию вкладчицы Пелагеи Бестужевой «с протчими ее советницы», ни одна из сестер не признала особой роли вкладчицы в организации поездки монахини Екатерины в Остречины к поповскому старосте [5, л. 1об.]. Напротив, все подчеркивали, что монахиня Екатерина была «соборной», то есть исполняла поручение от имени всей общины, которая традиционно собиралась для решения важных дел в специально отведенной для этого «соборной келье» $[5$, л. 16, 19].

\section{Вкладчики: статус в монастыре}

Однако в центре споров оказалась не новоиспеченная казначея, а вкладчица - Пелагея Бестужева. Монахиня Пелагея Свеча обвиняла ее в «зазорном» поведении и приводила в доказательство разные случаи. Так, ей было известно, что вкладчица якобы не раз ходила с монастырским «работником» Семеном Щепихиным «наедине в лес и по чюланам, и в анбаре» запиралась «часа по два и по три, и болши, знатно что для блуднаго дела» [5, л. 1об.]. Она ссылалась также на свидетельство жителя соседнего Оштинского погоста Евсея Иванова Кагача, который будто бы видел, как «вдова, будучись на Оште, была запиравшись с ним Семеном под кельей у девки Елены Ивановой» [5, л. 2]. Затаив недовольство, сразу после избрания в строительницы Пелагея Свеча прилюдно «учала ей вдове $<\ldots>$ говорить и воспрещать, чтоб оне такова беззакония в монастыре не творили и вышли б из монастыря, и зазору и поношения монастырю не наводили» $[5$, л. 1$]$.

В ходе допроса не нашлось ни одного человека, который мог бы подтвердить показания Пелагеи Свечи. Оштянин Евсей Кагач так и не был пойман. Отметим, что в 1707 г. - за двенадцать лет до спора - его «двор и участок» в деревне Мишковской пустовал, а сам он, по свидетельству односельчан, зафиксированному писцом Михаилом Мордвиновым, «сшел в 705-м году в Вытегорский погост» [11, л. 255]. Об обстоятельствах жизни оштянина был неплохо осведомлен ландрат Петровских заводов Григорий Муравьев. Он заверил епископа Корельского и Ладожского Аарона (Еропкина), что Евсей Кагач «превеликий пьяница и безделник» [5, л. 8об.]. Подобное свидетельство, возможно несколько преувеличенное, позволяет 
Социальная история

DOI: $10.7256 / 2222-1972.2015 .5 .17277$

все же предположить, что «доноситель» не раз посещал кабаки. Пелагея Свеча вполне могла его встретить в одном из двух кабаков деревни Княжбор [5, л. 5].

Показания сестер позволяют реконструировать по крупицам обстоятельства жизни вкладчиков обители. Сопоставление выявленных сведений с информацией, обнаруженной в других источниках и в литературе, позволяет уйти от однозначных оценок, диктуемых нарративом, который был составлен в канцелярии новгородского митрополита.

Как удалось установить, вкладчица Пелагея была выдана замуж за новгородского дворянина Ивана Тихоновича Бестужева, находившегося в конце 1690-х гг. на государственной службе. Е. В. Анисимов и Т. А. Базарова выявили, что в 1699 г. Иван Бестужев ездил в Швецию для контроля за качеством отлива на шведских заводах трехсот пушек $[12,29]$. Своего мужа Пелагея Бестужева потеряла в годы Северной войны. Она вспомнила, что стала жить «на монастырских хлебах и харчах <...> по указу блаженные памяти преосвященного Иова митрополита», занимавшего новгородскую кафедру с 1697 по 1716 гг. [13]

Строительница, не считаясь с высоким социальным статусом вдовы, отвела ей место в многолюдной келье, в которой ютились четыре монахини и столько же белиц [5, л. 3]. Тем не менее по традиции, сложившейся в соседних карельских монастырях, в том числе мужских Клименецком, Муромском и Палеостровском, Пелагея Бестужева проживала в обители «у вкладу своего» $[5$, л. Зоб.; 7, 16; 14, л. 5; 15, 50].

Почти все насельницы на допросе свидетельствовали, что в монастырской усадьбе у вкладчицы был свой собственный амбар [5, л. 2]. Духовник общины - иеромонах Лаврентий - и казначея Варвара, называя амбар «чуланом», знали, что в нем лежала «всякая скарба» [5, л. 15-16]. Монахини Екатерина, Анна, Евфимия, Улита и Маремьяна уточняли, что в том амбаре хранились «всякие припасы и платье», принадлежавшие не только вдове, но и монастырскому работнику Семену Щепихину [5, л. 16об.]. Сестры отмечали, что вкладчица «монастырского работника $<\ldots>$ при себе держит и в ключах у ней <...> он ходит» [5, л. 18об.]. Для учета хранившегося здесь имущества и для других хозяйственных нужд вдова вполне могла проводить в своем амбаре «часа по два и по три и болши», в том числе со своим ключарем. Несмотря на это, для некоторых новоначальных сестер, в том числе Пелагеи Свечи, подобные прецеденты становились основанием для пересудов.

Семен Щепихин не только исполнял обязанности ключаря. Оправдываясь, Пелагея Бестужева подчеркнула, что он жил при обители «и до ней лет за десять у вкладу своего в монастырской работе» [5, л. 3об.]. Вероятно, хранить имущество в одном амбаре им было намного проще.

Помимо распоряжения движимым имуществом, вкладчица Пелагея Бестужева продолжала управлять своим поместьем, покидая монастырь на длительный срок. Об этом был осведомлен епископ Корельский и Ладожский Аарон (Еропкин), который по личной просьбе вдовы Пелагеи собственноручно отпустил ее в октябре 1719 г. «в вотчиныя <...> деревни <...> на два месяца» до окончания розыска [5, л. 40].

От внимания монахини Пелагеи Свечи не ушло и то обстоятельство, что вдова бывала в Оштинском погосте, где будто бы запиралась «с ним, Семеном, под кельей у девки Елены Ивановой» [5, л. 2]. Нам удалось установить, что у Елены Ивановой, чья изба находилась недалеко от церковного амбара, нередко хранили свои товары проезжавшие через оштинскую таможню новгородские и белозерские купцы [16]. Это обстоятельство наталкивает на мысль, что вкладчики не только бережно хранили свое имущество, но и приумножали его, участвуя в торговых операциях.

Постоянное попечение о мирском занимало большую часть времени вкладчиков, не позволяя во всем следовать монастырскому уставу. Их жизнь превращалась в источник соблазна для тех, кто собирался принять или уже принял постриг и дал обет отрешиться от всего земного. В. М. Верюжский установил, что проживание вкладчиков в обители соседней Холмогорской епархии - особенно в тех случаях, когда их число превышало число братии, - приводило к серьезному ослаблению дисциплины и обмирщению монашества $[8,279,289]$. По выражению М. М. Богословского, монастырь нередко превращался «в многолюдную богадельню, оказывающую приют лицам, вступившим с ним в особую сделку» $[9,83]$.

Подчеркнем, что проживание в Вознесенском монастыре вкладчиц и вкладчиков не было явлением исключительным. А. И. Никитский, обращаясь к сведениям летописей, преданий и актов приказного делопроизводства, установил, что в XV-XVI вв. в состав монашеских общин 


\section{Исторический журнал: научные исследования № 5 (29) • 2015}

DOI: 10.7256/2222-1972.2015.5.17277

входили «два элемента» - «старцы и вкладчики». При этом автор подчеркнул, что в Новгородской епархии функционировали такие монастыри, в которых под началом игумена «находились как чернецы, так и черницы» $[17,53]$. Существование подобных практик в обителях «Северной Руси» А. И. Никитский связал, с одной стороны, с глубоко укоренившимися традициями особножития, согласно которым все «члены монастыря» проживали раздельно, имели свое имущество и отдельное хозяйство, а с другой стороны, с отсутствием в общежительных монастырях письменных уставов [17, 52-53].

В. М. Верюжский и А. Я. Ефименко установили, что в последней трети XVII - первой половине XVIII вв. в соседней Холмогорской епархии при некоторых мужских обителях проживали не только вкладчики с семьями, но и женщины разного социального статуса - монахини, девицы и вдовы $[8,260 ; 9,83]$. В. М. Верюжский объяснял развитие подобной практики особым статусом вкладчиков, которые постепенно стали принимать все большее участие в хозяйственной жизни обителей, а также с недостатком в епархии женских общежительных монастырей [8, 296].

Распорядители монастырской казны: община, поповский староста, вкладчица?

Отрицая обвинения в «пропое хлеба и харчю», казначея Пелагея Свеча заявляла, что в течение лета 1719 г. монастырскую казну растратила не она, но ее «истощили» поповский староста и вкладчица [5, л. 12].

Челобитчица привела подробную роспись расходов на содержание священника и его свиты во время его визитаций в монастырь в апреле и в июне 1719 г. При этом Пелагея Свеча полагала, что священник брал деньги из монастырской казны «с принуждения» и «просил» у сестер «келейные» деньги в качестве «взяток» [5, л. 1-2].

Однако ни одна из сестер не подтвердила этих обвинений. Напротив, бывшая казначея Варвара свидетельствовала, что деньги из монастырской казны расходовались «по приказу <..> оной строительницы Феклы с сестрами» [5, л. 16об.]. Кроме того, проверив сметы, монахиня Варвара разъясняла, что в первый приезд на священника и его помощника из казны «хлеба и харчю <...> изошло <...> на рубль, а не на шесть рублей». Монахини Екатерина, Анна, Евфимия, Улита, Маремьяна и иеромонах Лаврентий под- черкнули, что и тот и другой были «довольствованы <...> равною пищею» [5, л. 14, 17-18].

Сомневались сестры и в том, что во время второго визита священника из монастырской казны было израсходовано «близ дватцати рублев» [5, л. 2]. Никто из них не знал и о взятках, со слов Пелагеи Свечи переданных ему монахиней Екатериной (5 рублей), вкладчицей Пелагеей Бестужевой (более 2 рублей), монахиней Антонидой (3 рубля), пономарем Михаилом и старицей Ираидой (5 рублей) [5, л. 1-2]. Более того, насельницы были убеждены, что поповский староста приезжал к ним не по своей воле, но «за монастырским делом» $[5$, л. 5$]$.

Помимо претензий по расходованию монастырской казны, монахиня Пелагея Свеча считала вкладчицу Пелагею Бестужеву и ее ключаря Семена Щепихина виновными в убытках, которые монастырь понес летом 1719 г. В частности, в июле 1719 г. в устье р. Свирь пришли «с Вытегорской пристани торговые карбасы», для спуска которых отправился Семен Щепихин с двумя монастырскими «спущиками» $[5$, л. 5]. По мнению Пелагеи Свечи, монастырская казна потерпела убыток более чем на 60 рублей только потому, что Семен Щепихин «не управил и постановил на луду» два карбаса, в то время как остальные спустили местные крестьяне, которые не поделились с монастырем своей прибылью [5, л. 2, 5об.]. Если доверять сведениям «спущика» Козьмы Баженова о том, что с одного карбаса взималось «спусковых» денег по 3-4 рубля, то в Онежское озеро было переправлено в те дни 15-20 судов [5, л. 20].

Выступая в защиту Семена Щепихина, вкладчица Пелагея Бестужева заявила, что «неуправление тем карбасам тогдашняго ради ветра учинилось». Она объясняла, что уже в течение двух лет крестьяне отказывались делиться с монастырем доходами от «спусковых» денег, право сбора которых сестринская община унаследовала от упраздненного Вознесенского мужского монастыря [4, 72]. По утверждению вкладчицы, Пелагея Свеча прилюдно «ималася управится» с крестьянами, однако свое обещание так и не исполнила [5, л. 5].

Таким образом, насельницы и вкладчица доказывали, что распоряжение монастырской казной находилось в руках казначеи, которая вопреки сложившейся традиции расходовала деньги не с общего согласия общины, но по своему усмотрению. 


\section{Архаичная традиция особножития}

Предметом обсуждения стала не только жизнь вкладчицы, но и монахини Антониды, которую некоторые насельницы прочили в строительницы. Пелагея Свеча вменяла ей в вину нарушение общежительного устава. Согласно ее свидетельству, монахиня Антонида - в отличие от других сестер - «жила в том монастыре от других особлево и харчевничала хлебом и мясом и рыбою» [5, л. 1об.]. Пелагея Свеча полагала, что поповский староста Дмитрий Евтифеев утвердил монахиню Антониду на должность строительницы «к присмотру монастыря до указу» только потому, что получил от нее «взятку» - «три рубли да полотна несь сколько аршин, да с <...> вдовы Пелагеи два рубли» [5, л. 1об.].

В то же время поповский староста Дмитрий Евтифеев заявлял, что принял от монахини Антониды не «взятку», а «подношение», однако не считал необходимым оправдываться за свое решение перед новгородским владыкой. Согласно определению церковного собора 1667 г., монахам и монахиням запрещалось вести «всяческий торговый промысл», но разрешалось продавать предметы собственного рукоделия «в потребу пищи и одеяния, и иных ради телесных нужд» с разрешения игумена или игуменьи [18, 701]. Указ от 30 декабря 1701 г. даже поощрял эту практику, если доход шел в пользу всей общины. В частности, в нем отмечалось, что «древние монахи сами по себе трудолюбными своими руками пищу промышляли и общежительно живяше, и многих нищих от своих рук питали» $[6,182]$.

Размер «подношения» убеждает в том, что инокиня получала неплохой доход от промысла, чем и вызвала уважение сестер. По свидетельству самого поповского старосты, в знак благодарности за утверждение на должность строительницы он получил от монахини Антониды «полотна аршин десять <..> в почесть» $(7,1 \mathrm{~m})$ [5, л. 27].

Свидетельства из жизни монахини позволяют заключить, что в монастыре бытовали архаичные традиции особножития, согласно которым «монахи сами заботились о материальных основах своего существования (пище, одежде), а литургическая жизнь проходила по церковному уставу» $[19,120]$. «Особные» монастыри, получившие широкое распространение в центральном и северо-западном регионах Московского государства в более ранний период в XV-XVI вв., - стали предметом нареканий со стороны церковной администрации. Несмотря на то что в Новгородской епархии реформа по введению в них общежительного устава была начата еще при архиепископе Макарии в 1528 г., они продолжали функционировать в отдаленных карельских приходах еще во второй половине XVI в. [19, 121]. К их числу Е. Б. Емченко отнесла Шунгский Ильинский и Олонецкий Рождественский монастыри, упоминания о которых зафиксированы в писцовых книгах Заонежских погостов 1582/1583 и 1628-1631 гг. [1, 255-256]. Несшие здесь молитвенный подвиг «старицы» впоследствии были переведены в первые женские общежительные обители - Вознесенскую и Андрусовскую [2, 24; 4, 73].

\section{Пути преодоления конфликта: позиция епархиальной администрации}

Стремясь добиться умиротворения внутри общины, епархиальные власти действовали решительно. Вкладчица Пелагея Бестужева и поповский староста Дмитрий Евтифеев были почти сразу высланы в Великий Новгород, где в это время уже находилась Пелагея Свеча [5, л. 1, 3, 10].

Не дожидаясь окончания следствия, в ноябре 1719 г. епископ Корельский и Ладожский Аарон (Еропкин) нарушил традицию самостоятельного выбора общиной строительницы и назначил собственной властью на эту должность монахиню Агафью из рода помещиков Карсаковых [5, л. 23]. Подобные шаги, способствовавшие упорядочению иноческой жизни, церковная иерархия предпринимала не раз в последней трети XVII в. Так, В. М. Верюжский установил, что в 1680-1690-е гг. архиепископ Холмогорский Афанасий часто ставил в игумены своих кандидатов, «не сообразуясь с желанием братии» [8, 317-318]. В первые десятилетия XVIII в., как выявил М. И. Горчаков, Монастырский приказ довольно часто «назначал, избирал и утверждал настоятелей монастырей»с целью «восстановить строгую иноческую жизнь» $[20,169,172]$.

Новая строительница Агафья прибыла в монастырь поздней осенью 1719 г., так как до этого ни челобитчица Пелагея Свеча, ни ответчики не упоминали о ней в качестве свидетельницы [5, л. 1, 3-7, 26-28]. Монахиня Агафья не разделяла ничьих убеждений и по сравнению с другими сестрами имела высокий социальный статус. Ее кандидатура устраивала «всех того 


\section{Исторический журнал: научные исследования № 5 (29) • 2015}

DOI: $10.7256 / 2222-1972.2015 .5 .17277$

монастыря монахинь и вкладчиков», которые в ноябре 1719 г. подали челобитную с просьбой о наказании монахини Пелагеи Свечи и оправдании вкладчицы [5, л. 42].

Духовный судия Серапион Аничков со всей серьезностью отнесся к обвинениям в адрес священника Дмитрия Евтифеева, который был почти сразу отстранен от занимаемой должности. Обязанности поповского старосты возложили на священника Тимофея Никифорова из соседней Гежесельской волости Оштинского погоста [5, л. 42]. Однако ведение следствия Серапион Аничков доверил тем людям, которых лично знал: подьячему Василию Подьяконову и стряпчему Богдану Неелову [5, л. 2, 32].

Слушание дела в присутствии епископа Корельского и Ладожского Аарона (Еропкина) состоялось между 23 ноября 1719 г., когда в канцелярию поступил розыск, и 19 января 1720 г. Протоколы заседания не сохранились, однако о его результатах можно составить некоторое представление на основании отдельных свидетельств, выявленных в материалах судебного дела.

За поповского старосту ходатайствовали перед епископом Аароном (Еропкиным) ландрат Петровских заводов Григорий Муравьев и новая строительница монастыря Агафья с сестрами [5, л. 42-43]. Ландрат уверял владыку в том, что священник был «человек <..> доброй, и чрез доволное время не токмо чтоб мы сами в нем какова безпорядочного обходителства и неискуства усмотрить могли, но и от посторонних здешних обывателей не слыхали» [5, л. 8об.]. Заявления ландрата отчасти подтверждаются сведениями из жизни священника, которые удалось установить. В частности, к началу тяжбы Дмитрий Евтифеев состоял священником в причте церквей Остречинского погоста уже более двенадцати лет и около восьми лет занимал должность поповского старосты [11, л. 201; 16].

Так и не были пойманы Евсей Кагач, на показания которого ссылалась монахиня Пелагея Свеча, и монастырский «работник» Семен Щепихин [5, л. 22-23]. Доводы Пелагеи Свечи относительно расходования монастырской казны в течение лета 1719 г. не сходились с показаниями насельниц и священнослужителей обители. Все это предопределило исход дела. Из челобитной священника с просьбой об отпуске домой узнаем, что епископ Аарон (Еропкин) «указал» его «во всем оправить, а ее, монахиню Пелагею, обвинить» [5, л. 25об.]. Спустя год - в 1720 г., - будучи в возрасте 62 лет, он продолжил служить (вплоть до 1723 г.) в родном приходе [21, л. 50об.].

Уверенно полагаем, что вкладчица Пелагея Бестужева вернулась в монастырь. Об этом позволяет судить не только заступничество за нее сестер, но и их заботы, связанные с высылкой ей посылки в Великий Новгород. Казначея Варвара сообщала, что по решению новой настоятельницы монахиня Феодора повезла вкладчице деньги (десять рублей) и следующие съестные припасы: «четверть муки ржаной» (около 119 кг), «овсянные муки, толокна и круп по четверику» (по 24-26 л), «тринатцать хлебов печеных и рыбы тритцать сигов, икры полведра, масла коровья фунтов з десять и больше» (около 4 кг) [5, л. 18]. Объем хлеба и размер суммы вполне соответствовал окладу, который согласно указу от 30 декабря 1701 г. полагалось выдавать всем «начальным» и «подначальным» монахам («по 10 рублев денег, по 10 четвертей хлеба и дрова в довольность их») [6, 182].

Монахиня Пелагея Свеча, по всей видимости, была привлечена к ответственности, однако не только за недавнее самоуправство. В поданной владыке в ноябре 1719 г. челобитной сестры указали, что она «напред сего при матери своей <..> так и в нынешнюю пред пострижением и по пострижении своем бытности многая учинила в том монастыре разорения и <..> всенесносные обиды» [5, л. 42]. Со слов монахини Феодоры, при митрополите Корнилии, который занимал кафедру с 1674 по 1695 гг, «по повелению бывшей <...> строителницы монахини Анны с сестрами» Пелагея Свеча с матерью привлекались к суду за то, что украли из обители жалованные грамоты, крепости и «церковные утвари - Евангелия напрестолнаго и прочих вещей» [5, л. 42об.].

\section{Вызовы времени: новые веяния в традиционном укладе жизни обители в годы церковных реформ Петра I}

Учреждение Вознесенского Свирского общежительного женского монастыря стояло в ряду прочих мер, предпринятых церковными иерархами в северо-западных епархиях в последней четверти XVII в. с целью упорядочения иноческой жизни, борьбы с расколом и усиления контроля за духовной жизнью населения в крае с развитыми традициями общинного самоуправления. 
Внутренний уклад жизни сестер был пронизан множеством архаичных традиций. Coхранявшееся право самостоятельного выбора кандидатуры на должность строительницы в последней трети XVII - первой трети XVIII вв. превратилось в источник постоянных разногласий не только в Вознесенской обители. Так, Ю. Н. Кожевникова пришла к выводу, что в расположенной в юго-западном Прионежье Яшезерской пустыни в 1720-е гг. строителями оказывались «строители-временщики», «самоуправство» которых «наносило заметный ущерб небольшому монастырскому хозяйству» $[22,96]$. Выборы стали полем борьбы честолюбивых лиц, порой прибегавших к уловкам и махинациям, чтобы добиться утверждения той или иной кандидатуры. В результате к власти в монастырях приходили люди, не отличавшиеся высокими нравами и духовной жизнью.

Ожидая подтверждения избрания в строительницы, Пелагея Свеча стала растрачивать монастырскую казну по собственному усмотрению. А. И. Никитский подчеркнул, что в текстах уставных грамот и завещаниях основателей монастырей XIV-XVI вв. принцип соборного принятия решений, в том числе относительно расходования денег, выдвигался в качестве одного из ключевых в организации управления общежительным монастырем: «Всякое уклонение от него порицалось как незаконное» [17, 57]. Всеобщее недовольство, которое вызвала Пелагея Свеча, убеждает в том, что в Вознесенском монастыре в целом утвердились традиции общежития, которые тем не менее тесно переплетались с архаичными практиками особножительства.

Поведение Пелагеи Свечи - так же, как и тех монахов, которые занимали должности строителей в соседней Яшезерской пустыни, - с нашей точки зрения свидетельствует об их стремлении к независимости от общины, разрыву с традициями соборности. Из-за отсутствия должного уровня образования и необходимых духовных качеств подобные попытки оборачивались деспотическим всевластием [22, 96]. С учетом этого обстоятельства, видимо, и следует оценивать довольно часто предъявляемые во второй половине XVII - первой четверти XVIII вв. к таким «строителям» и «строительницам» достаточно схожие обвинения в «неистовстве» или «неистовом» житии [5, л. 4; 22, 96].

Подобные житейские ситуации приводили епархиальную администрацию и светские власти к мысли об отказе от традиции выбора настоятеля или настоятельницы и постепенному введению практики назначения на эту ответственную должность. Однако политика государства не была последовательной. Как подчеркнула Ю. Н. Кожевникова, указом Екатерины I от 14 марта 1727 г. «маловотчинным и безвотчинным монастырям и пустынькам» была вновь дарована самостоятельность, в том числе в выборе строителей [22, 95].

Еще одна архаичная черта в укладе жизни обители заключалась в сохранении за вкладчиками, давшими пожертвование на пострижение в старости, особого статуса. В конечном счете, их жизнь в монастыре становилась своего рода камнем преткновения и источником соблазнов для новоначальных. Проживая в обители бок о бок с инокинями и белицами, вкладчицы продолжали вести мирскую жизнь: распоряжались завещанным в монастырь имуществом, стремились приумножить его, свободно покидали обитель. Те из них, которые подобно Пелагее Бестужевой имели дворянское происхождение и/или давали большой вклад, рассчитывали на должное отношение к своей особе со стороны монахинь и стремились принимать активное участие во внутренней жизни общины. В. М. Верюжский установил, что в некоторых небольших обителях Холмогорской епархии вкладчики нередко занимали должности казначеев, заведуя монастырской казной [8, 260-261]. О той значимой роли, которую играли в жизни карельских монастырей вкладчики, позволяет судить и свидетельство, выявленное Ю. Н. Кожевниковой. Исследовательница отметила, что в Яшезерской пустыни в сентябре 1721 г. возник конфликт «между двумя группами вкладчиков, каждая из которых поддерживала своего кандидата в строители» [22, 89]. Против всевластия вкладчиков, которые порой определяли жизнь общины, скорее всего и была направлена деятельность приходивших к власти в монастырях «временщиков».

Бытование разных архаичных традиций во внутреннем укладе жизни обители - на фоне борьбы за власть и влияние - приводило к ослаблению нравственной и духовной дисциплины, к разобщению инокинь и обмирщению их жизни. Светская власть имела достаточно поверхностное представление о том, что происходило в монастырях на периферии. Это представление в большинстве случаев складывалось из почерпнутых в челобитных монахинь и вкладчиц 


\section{Исторический журнал: научные исследования № 5 (29) • 2015}

DOI: $10.7256 / 2222-1972.2015 .5 .17277$

взаимных тяжких обвинений в пьянстве и разврате, за которыми скрывалось нечто большее.

По утверждению Ю. Н. Кожевниковой, небольшие карельские монастыри «практически были предоставлены сами себе», и церковные власти «с большим опозданием» узнавали «о событиях, происходивших» в них [22, 96]. Изученные материалы судебного дела позволяют сделать вывод, что епархиальная администрация осуществляла управление приходами и монастырями Заонежской десятины через своих слуг и поповских старост и довольно быстро реагировала на жалобы с мест.

Однако поповские старосты, хотя и имели солидный опыт служения в храме и в приходе, не могли - по семейным обстоятельствам и по долгу службы - постоянно контролировать жизнь монахинь [23, 238]. Имея достаточно обширные полномочия, они - как и приезжавшие из Новгорода подьячие - оказывались в центре не утихавших споров: заинтересованные лица шли на многочисленные уловки, чтобы склонить их на свою сторону.

В то же время принцип соборности позволял общине - в случае ее сплочения и представительности - вести борьбу с всевластием отдельных должностных лиц и отстаивать свои интересы. Несмотря на серьезные недостатки в нравственной дисциплине, Вознесенский монастырь оставался значимым духовным центром округи. Об этом свидетельствует хотя бы то, что в 1730-х гг. в обход законодательства в обители продолжал совершаться постриг [3, 66]. Жители из соседних деревень и выставок приезжали сюда, чтобы поработать по найму в течение сезона, сделать пожертвования или помолиться Богу и получить духовное утешение.

\section{Библиография:}

1. Емченко Е. Б. Женские монастыри в России // Монашество и монастыри в России. XI-XX века: Исторические очерки / Отв. ред. Н. В. Синицына. М.: Наука, 2002. С. 245-284.

2. Чернякова И. А. Андрусов монастырь на пороге Нового времени: к истории старообрядчества в Карелии // Ученые записки Петрозаводского государственного университета. Сер.: Общественные и гуманитарные науки. 2008. № 4 (97). C. $15-30$.

3. Кожевникова Ю. Н. Монастыри и монашество Олонецкой епархии во второй половине XVIII - начале XX в. Петрозаводск: Издательство Спасо-Кижского Патриаршего Подворья, 2009. 304 с.

4. Кожевникова Ю. Н. Новый письменный источник по истории Вознесенской пустыни // Вестник Карельского краеведческого музея / Ред. колл. М. Л. Гольденберг, М. М. Шахнович, Д. Н. Кузнецов. Петрозаводск: Национальный музей РК, 2011. Вып. 6. С. 71-75.

5. Следственное дело по доносу на священника Остречинского погоста Дмитрия Евстафьева, обвиняемого в прелюбодеянии и взяточничестве. Июль 1719 г. - январь 1720 г. // Государственный архив Новгородской области. Ф. 480. Оп. 1. Д. 42.

6. Именный указ, объявленный боярином Мусиным-Пушкиным Монастырскому приказу. 0 выдаче монахам денежнаго и хлебнаго жалованья по единообразному окладу, о сборе доходов с монастырских вотчин в Монастырский приказ, об оставлении в монастырях токмо нужнаго числа служек и об употреблении остаточных монастырских доходов на содержание бедных монастырей и богаделен. 30 декабря 1701 г. // Полное собрание законов Российской империи. Собр. 1. Т. 4 (1700-1712). СПб.: Типография ІІ Отделения СЕИВК, 1830. № 1886. С. 181-182.

7. Барсов Е. В. Олонецкий монастырь Клименцы с приписными к нему пустынями, царскими и иераршими грамотами // Чтения в Императорском обществе истории и древностей российских при Московском университете. Ч. 2. Материалы отечественные. М.: Университетская типография на Страстном бульваре, 1871. Кн. 4. С. 1-171.

8. Верюжский В. М. Афанасий, архиепископ Холмогорский. Его жизнь и труды в связи с историей Холмогорской епархии за первые 20 лет ее существования и вообще Русской церкви в конце XVII в. Церковно-исторический очерк. СПб.: Типография И. В. Леонтьева, 1908. 683 с.

9. Богословский М. М. Земское самоуправление на Русском Севере в XVII в. Т. 1. Областное деление Поморья. Землевладение и общественный строй. Органы самоуправления. М.: Императорское общество истории и древностей российских при Московском университете, 1909. 322 с.

10. Бовыкин В. В. Общежитийные монастыри и развитие самоуправления в Русском государстве XV-XVI вв. // Исторические, философские, политические и юридические науки, культурология и искусствоведение. Вопросы теории и практики. 2012. № 8 (22). Ч. 1. С. 54-58.

11. Переписная книга частновладельческих, монастырских и дворцовых крестьян Оштинской половины Олонецкого уезда М. Л. Мордвинова. 1707 г. // Российский государственный архив древних актов. Ф. 1209. Оп. 1. Кн. 8578. Л. 110-612.

12. Анисимов Е. В., Базарова Т. А. Документы о Великом Новгороде эпохи петровских преобразований в Архиве СПб ИИ РАН // Вестник Новгородского государственного университета. Сер.: Гуманитарные науки. 2006. № 38. С. 28-32.

13. Иов, митрополит Новгородский: биография // [Электронный ресурc] - URL: http://vn-eparhia.ru/svyatiteli-novgorodskojzemli/151-svyatiteli-novgorodskoj-zemli-xix-vek/957-iov-mitropolit-novgorodskij (дата обращения: 14.09.2015).

14. Царская грамота из Приказа Большого дворца в Олонец воеводе стольнику князю В. Ф. Долгорукому и дьяку И. Уланову о переводе инокинь Успенского Муромского монастыря в Вознесенский Свирский и Никольский Брусицкий монастыри и о возвращении Муромского монастыря с его вотчинами инокам, временно переведенным в другие монастыри. 19 марта 1688 г. // Архив Санкт-Петербургского института истории РАН. Ф. 172. Д. 555. 
Социальная история

DOI: $10.7256 / 2222-1972.2015 .5 .17277$

15. Суслова Е. Д. Палеостровский монастырь и локальное сообщество в раннее Новое время (по записям Синодика и актам приказного делопроизводства) // Вестник Тверского государственного университета. Сер.: История. 2013. № 35. Вып. 4. С. 44-61.

16. Суслова Е. Д. Церковный староста в повседневной жизни карельского прихода в конце XVII - начале XVIII в. // [Электронный ресурс] - URL: http://carelica.petrsu.ru/2014/Suslova_2014s.pdf (дата обращения: 15.09.2015).

17. Никитский А. И. Очерк внутренней истории церкви в Великом Новгороде. Ч. 2. Устройство Новгородской церкви в XIII в. // Журнал Министерства народнаго просвещения. 1879. Март. Ч. ССII. С. 1-66.

18. Выписка из деяний Собора, бывшаго в сем году в Москве. 0 лицах духовнаго ведомства, об устройстве судов патриаршаго и епископских, об имуществах домовых патриарших, епископских и монастырских, о новом разделении епархий, о благочинии церковном и монастырском, о супружестве священников, диаконов и причетников и об уничтожении царских жалованных монастырям грамот, испрошенных патриархом Никоном. 17 июня 1667 г. // Полное собрание законов Российской империи. Собр. 1. Т. 1 (1649-1675). СПб.: Типография II Отделения СЕИВК, 1830. № 412. С. 698-715.

19. Синицына Н. В. Типы монастырей и русский аскетический идеал (XV-XVI вв.) // Монашество и монастыри в России. XI-XX века: Исторические очерки / Отв. ред. Н. В. Синицына. М.: Наука, 2002. С. 116-149.

20. Горчаков М. И. Монастырский приказ (1649-1725): опыт историко-юридического исследования. СПб.: Типография А. Траншеля, 1868. 296 с.

21. Книга Олонецкого уезду церковником и других чинов разночинцом, которые в оклад не положены. 1720-1723 гг. // Российский государственный архив древних актов. Ф. 350. Оп. 2. Д. 2374.

22. Кожевникова Ю. Н. Пять веков истории. Благовещенская Яшезерская пустынь. Петрозаводск: Verso, 2014. 343 с.

23. Суслова Е. Д. Институт поповских старост в Карелии раннего Нового времени // Университеты в образовательном пространстве региона: опыт, традиции и инновации: Материалы VI региональной научно-методической конференции (г. Петрозаводск, 22-23 ноября 2012 г.). Петрозаводск: Издательство ПетрГУ, 2012. Ч. 2. С. 237-238.

\section{References (transliterated):}

1. Emchenko E. B. Zhenskie monastyri v Rossii // Monashestvo i monastyri v Rossii. XI-XX veka: Istoricheskie ocherki / Otv. red. N. V. Sinitsyna. M.: Nauka, 2002. S. 245-284.

2. Chernyakova I. A. Andrusov monastyr' na poroge Novogo vremeni: k istorii staroobryadchestva v Karelii // Uchenye zapiski Petrozavodskogo gosudarstvennogo universiteta. Ser.: Obshchestvennye i gumanitarnye nauki. 2008. № 4 (97). S. 15-30.

3. Kozhevnikova Yu. N. Monastyri i monashestvo Olonetskoi eparkhii vo vtoroi polovine XVIII - nachale XX v. Petrozavodsk: Izdatel'stvo Spaso-Kizhskogo Patriarshego Podvor'ya, 2009. 304 s.

4. Kozhevnikova Yu. N. Novyi pis'mennyi istochnik po istorii Voznesenskoi pustyni // Vestnik Karel'skogo kraevedcheskogo muzeya / Red. koll. M. L. Gol'denberg, M. M. Shakhnovich, D. N. Kuznetsov. Petrozavodsk: Natsional'nyi muzei RK, 2011. Vyp. 6. S. 71-75.

5. Sledstvennoe delo po donosu na svyashchennika Ostrechinskogo pogosta Dmitriya Evstaf'eva, obvinyaemogo v prelyubodeyanii i vzyatochnichestve. Iyul' 1719 g. - yanvar' 1720 g. // Gosudarstvennyi arkhiv Novgorodskoi oblasti. F. 480. Op. 1. D. 42.

6. Imennyi ukaz, ob"yavlennyi boyarinom Musinym-Pushkinym Monastyrskomu prikazu. O vydache monakham denezhnago i khlebnago zhalovan'ya po edinoobraznomu okladu, o sbore dokhodov s monastyrskikh votchin v Monastyrskii prikaz, ob ostavlenii v monastyryakh tokmo nuzhnago chisla sluzhek i ob upotreblenii ostatochnykh monastyrskikh dokhodov na soderzhanie bednykh monastyrei i bogadelen. 30 dekabrya $1701 \mathrm{~g}$. // Polnoe sobranie zakonov Rossiiskoi imperii. Sobr. 1. T. 4 (1700-1712). SPb.: Tipografiya II Otdeleniya SEIVK, 1830. № 1886. S. 181-182.

7. Barsov E. V. Olonetskii monastyr' Klimentsy s pripisnymi k nemu pustynyami, tsarskimi i ierarshimi gramotami // Chteniya v Imperatorskom obshchestve istorii i drevnostei rossiiskikh pri Moskovskom universitete. Ch. 2. Materialy otechestvennye. M.: Universitetskaya tipografiya na Strastnom bul'vare, 1871. Kn. 4. S. 1-171.

8. Veryuzhskii V. M. Afanasii, arkhiepiskop Kholmogorskii. Ego zhizn' i trudy v svyazi s istoriei Kholmogorskoi eparkhii za pervye 20 let ee sushchestvovaniya i voobshche Russkoi tserkvi v kontse XVII v. Tserkovno-istoricheskii ocherk. SPb.: Tipografiya I. V. Leont'eva, 1908. $683 \mathrm{~s}$.

9. Bogoslovskii M. M. Zemskoe samoupravlenie na Russkom Severe v XVII v. T. 1. Oblastnoe delenie Pomor'ya. Zemlevladenie i obshchestvennyi stroi. Organy samoupravleniya. M.: Imperatorskoe obshchestvo istorii i drevnostei rossiiskikh pri Moskovskom universitete, 1909. $322 \mathrm{~s}$.

10. Bovykin V. V. Obshchezhitinye monastyri i razvitie samoupravleniya v Russkom gosudarstve XV-XVI vv. // Istoricheskie, filosofskie, politicheskie i yuridicheskie nauki, kul'turologiya i iskusstvovedenie. Voprosy teorii i praktiki. 2012. № 8 (22). Ch. 1. S. 54-58.

11. Perepisnaya kniga chastnovladel'cheskikh, monastyrskikh i dvortsovykh krest'yan Oshtinskoi poloviny Olonetskogo uezda M. L. Mordvinova. 1707 g. // Rossiiskii gosudarstvennyi arkhiv drevnikh aktov. F. 1209. Op. 1. Kn. 8578. L. 110-612.

12. Anisimov E. V., Bazarova T. A. Dokumenty o Velikom Novgorode epokhi petrovskikh preobrazovanii v Arkhive SPb II RAN // Vestnik Novgorodskogo gosudarstvennogo universiteta. Ser: Gumanitarnye nauki. 2006. № 38. S. 28-32.

13. Iov, mitropolit Novgorodskii: biografiya // [Elektronnyi resurs] - URL : http://vn-eparhia.ru/svyatiteli-novgorodskojzemli/151-svyatiteli-novgorodskoj-zemli-xix-vek/957-iov-mitropolit-novgorodskij (data obrashcheniya: 14.09.2015).

14. Tsarskaya gramota iz Prikaza Bol'shogo dvortsa v Olonets voevode stol'niku knyazyu V. F. Dolgorukomu i d'yaku I. Ulanovu o perevode inokin' Uspenskogo Muromskogo monastyrya v Voznesenskii Svirskii i Nikol'skii Brusitskii monastyri i o vozvrashchenii Muromskogo monastyrya s ego votchinami inokam, vremenno perevedennym v drugie monastyri. 19 marta 1688 g. // Arkhiv Sankt-Peterburgskogo instituta istorii RAN. F. 172. D. 555.

15. Suslova E. D. Paleostrovskii monastyr' i lokal'noe soobshchestvo v rannee Novoe vremya (po zapisyam Sinodika i aktam prikaznogo deloproizvodstva) // Vestnik Tverskogo gosudarstvennogo universiteta. Ser.: Istoriya. 2013. № 35. Vyp. 4. S. 44-61.

16. Suslova E. D. Tserkovnyi starosta v povsednevnoi zhizni karel'skogo prikhoda v kontse XVII - nachale XVIII v. // [Elektronnyi resurs] - URL: http://carelica.petrsu.ru/2014/Suslova_2014s.pdf (data obrashcheniya: 15.09.2015). 


\section{Исторический журнал: научные исследования № 5 (29) • 2015}

\section{DOI: $10.7256 / 2222-1972.2015 .5 .17277$}

17. Nikitskii A. I. Ocherk vnutrennei istorii tserkvi v Velikom Novgorode. Ch. 2. Ustroistvo Novgorodskoi tserkvi v XIII v. // Zhurnal Ministerstva narodnago prosveshcheniya. 1879. Mart. Ch. SSII. S. 1-66.

18. Vypiska iz deyanii Sobora, byvshago v sem godu v Moskve. O litsakh dukhovnago vedomstva, ob ustroistve sudov patriarshago i episkopskikh, ob imushchestvakh domovykh patriarshikh, episkopskikh i monastyrskikh, o novom razdelenii eparkhii, o blagochinii tserkovnom i monastyrskom, o supruzhestve svyashchennikov, diakonov i prichetnikov i ob unichtozhenii tsarskikh zhalovannykh monastyryam gramot, isproshennykh patriarkhom Nikonom. 17 iyunya $1667 \mathrm{~g}$. // Polnoe sobranie zakonov Rossiiskoi imperii. Sobr. 1. T. 1 (1649-1675). SPb.: Tipografiya II Otdeleniya SEIVK, 1830. № 412. S. 698-715.

19. Sinitsyna N. V. Tipy monastyrei i russkii asketicheskii ideal (XV-XVI vv.) // Monashestvo i monastyri v Rossii. XI-XX veka: Istoricheskie ocherki / Otv. red. N. V. Sinitsyna. M.: Nauka, 2002. S. 116-149.

20. Gorchakov M. I. Monastyrskii prikaz (1649-1725): opyt istoriko-yuridicheskogo issledovaniya. SPb.: Tipografiya A. Transhelya, 1868. $296 \mathrm{~s}$.

21. Kniga Olonetskogo uezdu tserkovnikom i drugikh chinov raznochintsom, kotorye v oklad ne polozheny. 1720-1723 gg. // Rossiiskii gosudarstvennyi arkhiv drevnikh aktov. F. 350. Op. 2. D. 2374.

22. Kozhevnikova Yu. N. Pyat' vekov istorii. Blagoveshchenskaya Yashezerskaya pustyn'. Petrozavodsk: Verso, 2014. 343 s.

23. Suslova E. D. Institut popovskikh starost v Karelii rannego Novogo vremeni // Universitety v obrazovatel'nom prostranstve regiona: opyt, traditsii i innovatsii: Materialy VI regional'noi nauchno-metodicheskoi konferentsii (g. Petrozavodsk, 22-23 noyabrya 2012 g.). Petrozavodsk: Izdatel'stvo PetrGU, 2012. Ch. 2. S. 237-238. 